\title{
DE WALTER BENJAMIN A THEODOR ADORNO: TRAÇOS QUE PERMANECEM NA CONTEMPORANEIDADE
}

\section{FROM WALTER BENJAMIN TO THEODOR ADORNO: TRACES IN THE CONTEMPORANEITY}

\author{
Carolina Diamantino Esser Santana'
}

\begin{abstract}
RESUMO: $O$ ensaio traz como base a crítica ao capitalismo, no que se refere aos efeitos negativos que ele impóe aos indivíduos, a partir dos estudos da primeira geraçăo da Escola de Frankfurt. Analisar-se-á a história das ideias a partir de Walter Benjamin, Herbert Marcuse, Theodor Adorno e Max Horkheimer. Benjamin afirma que vive-se a perda da aura das obras de arte, já que a sua comercializaçăo faz com que se perca a essência daquelas obras. Ademais, a imposiçấo da novidade às obras e aos produtos consumidos representa uma ferramenta de manipulaçăo do capitalismo, culminando na pobreza da experiência humana. Marcuse afirma que a sociedade vive o princípio do desempenho, que provoca modos de vida uniformizados, baseados numa concepçấo de trabalho e diversăo homogêneos. Adorno propôs que o tempo livre provocava uma sensaçăo de liberdade nos indivíduos, mas, na realidade, tratava-se do exercício de uma năo liberdade, já que as formas de diversăo seguiam à risca os padróes exigidos pelo capital. A partir do método adotado pela própria Teoria Crítica, afirma-se que a presente discussáo teórica só se torna efetiva quando aplicada à prática, à sociedade atual.
\end{abstract}

PALAVRAS-CHAVES: Capitalismo; Escola de Frankfurt; Massificaçăo.

ABSTRACT: The theme of this essay is a critique of capitalism, regarding the negative effects it imposes on individuals, accordingly to the studies of the first generation of Frankfurt School. The analysis will be based on the perspectives of Walter Benjamin, Herbert Marcuse, Theodor Adorno and Max Horkheimer. Benjamin states that the society lives the loss of aura of Art, since its merchandising implies on the losses of their essence. Moreover, the imposition of "new" character for Art and consumer goods is a tool of manipulation of capitalism, culminating in a poverty of human experience. Marcusestates that societylives the principle of performance, which causesa"standard" mode of life, based on a homogeneous conception of work and entertainment. Adorno proposed that free time provoked a sense of freedom in individuals, but, in reality, it is a "non-freedom", since the forms of entertainment followed strictly the standards required by the capital. Following the method adopted by the Critical Theory itself, it states that the theoretical discussions are only effective when applied to the practice, to the current society.

KEYWORDS: Capitalism; Frankfurt School; Massification.

Mestre em Teoria do Direito pela Pontifícia Universidade Católica de Minas Gerais e Bacharel em Direito pelo Faculdade de Direito Milton Campos. Atualmente, reside na Alemanha, onde cursará o doutorado em Filosofia na Universidade de Vechta. caroldesser@yahoo.com.br 


\section{INTRODUÇÃO}

O presente ensaio parte do pressuposto de que a Teoria Crítica alemá permanece em voga. Apesar de se tratar de uma teoria surgida no início do século XX e que até hoje possui representantes de suas novas geraçôes, há um objetivo que sempre guiou a sua variedade de discussôes: a crítica ao capitalismo.

Por isso, o ensaio se propóe a revisitar a Teoria Crítica, a partir de autores que trataram dessa crítica de modo objetivo: Walter Benjamin, Herbert Marcuse, Theodor Adorno e Max Horkerheimer. O trabalho fará uma análise detalhada de suas principais obras, na tentativa de clarificá-las e rediscuti-las. Considera-se que referidas discussóes permanecem atuais e, portanto, de extrema relevância a discussăo da obra de referidos estudiosos.

\section{WALTER BENJAMIN, A PERDA DA AURA E A POBREZA DA EXPERIÊNCIA HUMANA}

Walter Benjamin nasceu em 1892 e faleceu em 1940. O autor estudou nas universidades de Berlim, Friburgo e Berna, doutorando-se com uma tese acerca da crítica da arte no romantismo alemăo em 1920 (MORA, 1988, p. 311).

Benjamin, apesar de mais velho que os demais integrantes, ainda assim participou da Escola de Frankfurt, no final dos anos vintes. Axel Honneth coloca Benjamin fora do círculo interno da Escola, afirmando que, em que pese a diretiva central de seu pensamento se aproximar do círculo interno, o ponto de divergência de Benjamin com a Teoria Crítica reside na questăo dos efeitos dos novos meios da moderna cultura de massa sobre a sociedade (HONNETH, 1999, p. 529). Para Benjamin, a luta cultural das classes sociais determina a capacidade de integraçăo da sociedade (HONNETH, 1999, p. 533), de modo que ele náo traz uma posiçăo tăo pessimista quanto a de Adorno, por exemplo.

Para Merquior (1969, p. 99), o fato de Benjamin năo ter vivenciado o período de exílio da Escola de Frankfurt nos Estados Unidos --- Benjamin optou por permanecer em Paris ---, talvez tenha feito com que ele năo carregasse, em suas obras, o chamado pessimismo frankfurtiano, de modo tăo preponderante como os outros integrantes da Escola.

Quanto a um menor pessimismo de Walter Benjamin, entende-se que talvez isso seja afirmado pelo fato de referido pensador nâo se ater somente a críticas ao sujeito burguês em si, mas, precipuamente, à questăo da arte de sua época. O seu enfoque é a produçâo artística e, nâo tanto, o comportamento dos indivíduos socialmente considerado.

A obra de Benjamin tem uma natureza fragmentada e compóe-se de apontamentos e intuiçôes, sem a mençâo objetiva a teses ou argumentos. É como se os seus escritos criassem uma atmosfera de ideias (MORA, 1988, p. 312) em vez de um raciocínio linear. Conforme bem explica Delacampagne:

Seus primeiros textos revelam imediatamente o seu interesse pela estética e pela história, sua simpatia pelas teses progressistas, suas afinidades com o romantismo e o expressionismo, sua curiosidade pela psicanálise, pela pintura moderna, pela arte 
popular, pelas ciências ocultas - mas também as dificuldades que experimenta em dar à profusăo das suas ideias uma expressăo organizada, de acordo com as normas acadêmicas. (DELACAMPAGNE, 1997, p. 141)

A partir dessa característica da obra de Benjamin, no presente ensaio serăo analisados alguns ensaios do autor que mais se aproximaram das críticas ao capitalismo no que se refere aos indivíduos, quais sejam: A obra de arte na era de sua reprodutibilidade técnica, Experiência e pobreza e Rua de mâo única. Além disso, serăo também analisados trechos da obra Passagens, na medida em que esta obra, sem dúvidas, é aquela que mais se aproxima do tema de estudo.

Benjamin năo analisa a sociedade da mesma forma como os demais teóricos da Teoria Crítica, haja vista o fato de manter o seu foco no estudo da arte e cultura:

Sem dúvida, ele [Benjamin] năo é um teórico da sociedade na acepçáo convencional do termo, pois mostra pouco interesse pela explicaçăo dos mecanismos de constituiçáo da sociedade. Todavia, existem suficientes elementos teórico-sociais em sua análise da cultura que revelam até onde suas concepçôes ultrapassaram o nível do pensamento funcionalista do instituto. (HONNETH, 1999, p.532)

Um dos principais pontos tratados por Benjamin é uma suposta perda da aura das obras de arte à sua época. É de se salientar, primeiramente, que o pensador reconhece que a evoluçáo da arte pode transformar a sociedade, a partir do seu maior poder de alcance. Flávio René Kothe destaca que Benjamin reconhece as possibilidades abertas pela tecnologia. Todavia, ao mesmo tempo, ele enxerga que a massificaçâo da arte traz efeitos ruins à sociedade.

Benjamin náo só pretendia criticar a arte de seu tempo, mas, trazer à discussăo a forma de interpretaçâo dessa arte. Ele pretende destacar o que a própria arte tem a dizer, sem interferências do sujeito-intérprete. Só a partir de uma relaçăo crítica entre arte e intérprete é que seria possível se resgatar a aura da obra de arte:

Benjamin questiona a perda da aura nos tempos modernos, especialmente devido à massificaçăo, que provoca a perda da experiência, "Através da padronizaçăo imperante na sociedade massificada, anula-se a categoria da diferença e a capacidade de perceber o diferenciado". (KOTHE, 1976, p. 40)

Sendo assim, a massificaçáo provoca a incapacidade de se identificar diferenças e características próprias das manifestaçóes artísticas, o que prejudica a sua aura. Benjamin, em A obra de arte na era da reprodutibilidade técnica traz uma definiçâo do que seria a aura:

Em suma, o que é a aura? É uma teia singular, composta de elementos espaciais e temporais: a apariçấo única de uma coisa distante, por mais perto que ela esteja. Observar, em repouso, numa tarde de veráo, uma cadeia de montanhas no horizonte, ou um galho, que projeta sua sombra sobre nós, significa respirar a aura dessas montanhas, desse galho. (BENJAMIN, 2012a, p. 184)

O fenômeno da massificaçăo, mais tarde desenvolvido também por Theodor Adorno e Max Horkheimer, faz com que haja uma submissăo das obras de arte a padróes previamente estipulados, promovendo a sua produçấo e interpretaçăo sempre de modo similar. A diferença, o poder da arte de inovar, de questionar a sociedade que a cerca de modo particular, estaria perdendo-se: “Pertencer à massa implica numa uniformidade 
que redunda em carência de percepçáo do diferenciado. Sendo a capacidade de perceber o diferenciado essencial à percepçăo estética, a massa é por natureza contraposta à arte." (KOTHE, 1976, p. 85).

A análise de Benjamin é ainda mais relevante porque reflete, indiretamente, na discussáo sobre a busca de padróes e uniformizaçăo năo só pelas obras de arte, mas, também, pelos indivíduos que habitam a sociedade de sua época. Benjamin, ao refletir sobre as obras de arte e a perda de sua aura, questiona também os jornais, como incentivadores da perda da possibilidade da experiência pelos indivíduos, incentivando a nâo comunicaçăo entre eles, a ausência de diálogo e formaçăo de opiniâo de modo livre. Kothe (1976, p. 84) afirma que, de acordo com a concepçâo de Benjamin, a perda da aura tem como um dos causadores a imprensa jornalística, porque ela causa o desaparecimento do espaço para a experiência, para a aproximaçăo entre algo distante no tempo ou espaço, para perto do sujeito:

\begin{abstract}
A informaçăo jornalística se caracteriza por quatro elementos: novidade, concisăo, comunicabilidade e năo-relacionamento das informaçôes isoladas. Em si, ela é contrária à formaçáo de experiência, pois esta se constitui pela correlaçăo e elaboraçáo de dados diversos, obtidos na trajetória entre um estado de carência, que faz com que se constitua um desejo ou anelo, e a realizaçăo - ou năo - dessa meta. A narrativa, o teatro e mesmo a poesia săo em geral o registro de tal trajetória. Nela, algo distante no espaço e/ou no tempo é trazido para perto: isso constitui a "aura" de tal narrativa, poema ou peça teatral. A ascensăo do jornalismo corresponde ao processo de perda dessa aura. A literatura é entăo o registro da experiência histórica. Ler é herdar esse patrimônio. A correria da multidăo pelas avenidas metropolitanas é precisamente o estado oposto à possibilidade de transmissâo dessa experiência. E essa multidăo constitui o público dos jornais. À medida que tal estado aparece como caracterizador da "vida moderna", a própria sobrevivência da arte se encontra em perigo, pois a experiência e a percepçáo diferenciada que ela pode transmitir náo encontra mais condiçôes de recepçăo. (KOTHE, 1976, p. 84)
\end{abstract}

Ou seja, o ritmo de vida acelerado dos indivíduos, fomentado pelos jornais, desconstitui o estado a eles necessário para a apreensáo da arte. A aura consiste na aproximaçăo, na trajetória entre o que é distante e o que é aproximado pela arte, e isso exige que o indivíduo esteja preparado para tal processo dialético. Ao trabalhar, por exemplo, a hermenêutica literária, Benjamin entende que, ao contrário do que ocorre no trabalho terapêutico, em que a descoberta do significado de um sintoma deve levar a um tratamento que o elimine, a hermenêutica literária, ao descobrir o significado, deve reconhecer ao significante a devida qualidade que lhe é própria (KOTHE, 1976, p. 21).

Benjamin afirma que o sentido trazido por um texto, um poema ou uma obra de arte, é sempre outro que năo somente aquele primeiramente visível, o que faz com que a submissâo dos indivíduos a ideologias e predeterminaçôes do que seja a arte prejudique sua intençăo, sua essência, sua aura.

A obra poética de Charles Baudelaire é estudada por Benjamin na obra Passagens. Para Benjamin, a análise da obra do referido poeta justifica-se "[...] pelo fato deste ter assumido a experiência de choque, vigente no cotidiano das metrópoles capitalistas, constituindo-a na lei fundamental de sua criaçâo poética. Esta acabava sendo, portanto, uma denúncia do modo de vida que provocava choques a todo momento" (KOTHE, 1976, p. 74). 
Benjamin chega a comparar Baudelaire à prostituta, já que, quando o poeta passa a vender seus poemas, ele escancara a sua intimidade, assim como a prostituta. A sua arte, que seria algo particular e específico, torna-se uma mercadoria a ser submetida à massa. Isso é como um marco da transformaçăo do ser humano em mercadoria.

A obra Passagens, uma miscelânea de ensaios e anotaçóes elaborados por Benjamin, faz uma análise năo só da obra de Baudelaire, mas também da realidade social daquele século em vários aspectos. Uma das questōes ali discutidas é sobre a qualidade do novo. Para Benjamin, o capitalismo e precipuamente a moda incentivam a sensaçăo de que os novos produtos săo diferentes de tudo antes já visto. $O$ novo é qualidade independentemente do valor de uso da mercadoria. $O$ inconsciente coletivo possui uma imagem produzida a partir da aparência alienante do novo. Nesse ínterim, a moda é o agente causador mais forte dessa falsa consciência. A partir disso, desenvolve-se nos indivíduos, que acreditam na novidade, a repetiçăo de algo que é sempre igual. A arte também passa a fazer do novo o seu valor supremo, almejando a utilidade a todo custo (BENJAMIN, 2006, p. 48).

A novidade da moda é uma falsa realidade. As mercadorias quase sempre năo trazem grandes novidades, mas conseguem convencer os consumidores disso, os quais desejam comprá-las a qualquer custo. O novo é, na realidade, sempre o mesmo.

Ora, este fenômeno na arte compromete, sem dúvida, o seu papel de crítica social. A arte só é arte quando carrega questionamentos à sociedade que a cerca, de modo particular e modificado a cada nova situaçáo. Com o fenômeno da uniformizaçáo, a arte perde a sua funçấo e os artistas acabam por manifestar um conformismo com a sociedade. Será visto que a noçăo da arte como uma ferramenta de denúncia e crítica social é uma constante para os pensadores da Teoria Crítica.

Com a alienaçấo dos indivíduos e a lógica mecanicista cada vez mais em voga, a moralidade torna-se desnecessária e surge a maquinaria feita de seres humanos: eles năo pensam, năo questionam, săo conformados e indiferentes uns aos outros. Benjamin afirma que a atividade comercial é imoral e passa a conduzir as condiçôes de vida das pessoas. A organizaçáo complexa do comércio funciona como uma maquinaria, que se reflete no domínio psicológico dos indivíduos (BENJAMIN, 2006, p. 41).

Até nas conversas do dia a dia, dirá Benjamin, o dinheiro, os valores do capital, substituem o real interesse pelo bem-estar dos sujeitos que integram o diálogo. A preocupaçăo com sentimentos é substituída por assuntos ligados ao capital. Benjamin afirma que a liberdade da conversa se está perdendo. Se antes, entre seres humanos em conversa, a consideraçâo pelo parceiro era natural, ela é substituída pela pergunta sobre o preço de seus sapatos ou de seu guarda-chuva. Benjamin afirma que, na sua sociedade, em toda discussâo entre as pessoas, o tema das condiçôes de vida e do dinheiro é uma constante. Nâo há mais o interesse pelas preocupaçóes e sofrimentos dos indivíduos, os quais talvez pudessem fazer com que se ajudassem uns aos outros (BENJAMIN, 2012c, p. 21).

Para Kothe, Benjamin, assim como Adorno, já discutia, no século XX, a distraçāo do sujeito típico da sua sociedade, a qual também pode ser visualizada no sujeito de massa dos tempos atuais. É o chamado estado de dispersăo do ouvinte ou do espectador moderno. A música passou a ser um fundo musical e, năo mais, um todo em si. Todos os 
mecanismos de reproduçáo e depressâo social obrigam as pessoas a conhecer determinadas cançōes e o fetichismo se instaura na arte (KOTHE, 1978, p. 49).

O fenômeno de distraçâo tratado por Benjamin é uma forma de alienaçáo, de submissăo ao entretenimento produzido pelo capitalismo, de maneira cega. Benjamin afirma que o indivíduo da massa de sua época possui uma pobreza de experiência, náo pretende criar sonhos e metas individuais, vive sua vida agitada sem parar, sem construir seus objetivos. Para Benjamin, o ser humano está pobre, foram empenhadas as peças do patrimônio humano, o valor de troca atingiu os indivíduos:

Pobreza de experiência: isso năo deve ser compreendido como se os homens aspirassem a novas experiências. Năo, eles aspiram a libertar-se de toda experiência, aspiram a um mundo em que possam ostentar tăo pura e tăo claramente sua pobreza, externa e também interna, que algo de decente possa resultar disso. [...] A existência do camundongo Mickey é um desses sonhos do homem contemporâneo. É uma existência cheia de milagres, que năo somente superam os milagres técnicos como zombam deles. [...] Natureza e técnica, primitividade e conforto unificam-se aqui completamente, e aos olhos das pessoas, fatigadas com as complicaçóes infinitas da vida diária e que veem a finalidade da vida apenas como o mais remoto ponto de fuga numa interminável perspectiva de meios, surge uma existência redentora que em cada dificuldade se basta a si mesma, do modo mais simples e ao mesmo tempo mais cômodo, na qual um automóvel náo pesa mais que um chapéu de palha, e uma fruta na árvore se arredonda como a gôndola de um balăo. [...] Ficamos pobres. Abandonamos, uma a uma, todas as peças do patrimônio humano, tivemos que empenhá-las muitas vezes a um centésimo do seu valor para recebermos em troca a moeda miúda do "atual". (BENJAMIN, 2012b, p. 127)

A análise benjaminiana do ritmo de vida dos indivíduos é uma constante. Em Passagens ele analisa os aspectos cotidianos da sociedade. A reflexâo sobre as grandes cidades é como uma síntese da perda da moralidade e da construçăo de um conformismo generalizado pelas pessoas de sua época. Em Rua de Mâo Única, Benjamin afirma que, assim como todas as coisas que estâo num irresistível processo de mistura e impureza, perdem sua expressăo de essência, assim também a cidade. As grandes cidades têm uma potência incomparavelmente tranquilizadora e corroborante, criando uma consciência das forças elementares sempre vigilantes. Por outro lado, há uma insegurança constante nas grandes cidades que faz com que o citadino viva uma situaçâo opaca e cruel no mais alto grau, em que ele tem de acolher em si, sob as inclemências da planície desolada, os produtos da arquitetônica urbana (BENJAMIN, 2012c, p. 23).

Ora, também nos dias atuais se verifica cada vez mais a influência da estrutura da cidade sobre os indivíduos, a maneira como a arquitetura urbana e o trânsito influenciam sobre a qualidade de vida dos sujeitos.

Benjamin também chama a atençăo para a perda da construçăo individual e privada de vida das pessoas. Para referido autor, as cidades fazem com que os indivíduos busquem, a todo custo, resgatar algo de privado, que lhes é retirado a todo momento, tudo é publicizado, tudo está na opiniâo pública, no ritmo da sociedade que o circunda:

O interior năo é apenas o universo do homem privado, é também seu estojo. Desde Luís Filipe, encontra-se no burguês esta tendência de indenizar-se da ausência de rastros da vida privada na grande cidade. Essa compensaçáo, ele tenta encontrala entre as quatro paredes de seu apartamento. Tudo se passa como se fosse uma 
questâo de honra náo deixar se perderem os rastros de seus objetos de uso e de seus acessórios. Infatigável, preserva as impressōes de uma multidāo de objetos; para seus chinelos e seus relógios, seus talheres e seus guarda-chuvas, imagina capas e estojos. Tem uma clara preferência pelo veludo e a pelúcia que conservam a marca de todo contato. (BENJAMIN, 2006, p. 60)

A metáfora utilizada por Benjamin, da utilizaçăo das capas e estojos, como forma de privatizar os objetos, é muito interessante. Hoje, as redes sociais comprovam que a colocaçăo de padrôes e formas de vida de modo cada vez mais público é recorrente. A vida privada e íntima das pessoas é exposta por elas próprias, o que se permite interpretar como uma tentativa de deixarem-se rastros, de construírem-se laços, assim como os estojos e as capas de veludo funcionavam, no início do século XX.

Benjamin afirma que os indivíduos, ainda na esfera privada, se guiam por instintos de massa, por noçóes externa e coletivamente impostas. As pessoas vivem um estranho paradoxo: têm em mente o mais estreito interesse privado quando agem, mas ao mesmo tempo săo determinadas mais do que nunca em seu comportamento pelos instintos da massa. Nesse contexto, os instintos de massa tornaram-se desatinados e alheios à vida. A sociedade, na qual cada um tem em mira unicamente seu próprio bem-estar, sucumbe, como massa cega, com letargia animal. A diversidade de alvos individuais torna-se irrelevante perante a identidade das forças determinantes. Há uma perda dos instintos vitalmente importantes, e impotência e declínio do intelecto (BENJAMIN, 2012c, p. 20).

Para Benjamin, o ser humano torna-se cada vez mais solitário e acredita fazer parte de um todo que, na realidade, é vazio. Os indivíduos passam a criar teorias sobre o futuro, as quais săo apenas ideias egoístas contaminadas pelo capitalismo. O pensador acredita que a cega vontade de salvar o prestígio da existência pessoal, de preferência a destacá-la, pelo menos, por meio da soberana avaliaçáo de sua impotência e de seu embaraço, impóe-se quase por toda parte. Ele afirma que o ar está cheio de teorias de vida e visóes do mundo, e que por isso elas fazem um efeito tăo pretensioso, porque no fim quase sempre valem como sançăo de alguma situaçấo privada totalmente insignificante. Dessa forma, sâo disseminadas pelos indivíduos alucinaçôes, miragens de um futuro cultural que, apesar de tudo, irrompe florescente da noite para o dia, porque cada qual se compromete com as ilusóes óticas de seu ponto de vista isolado (BENJAMIN, 2012c, p. 22).

Isso acontece justamente porque a moralidade se torna desnecessária em tal sociedade:

Todas as relaçóes humanas mais próximas săo atingidas por uma claridade penetrante, quase insuportável, na qual mal conseguem resistir. Pois, uma vez que, por um lado, o dinheiro está, de modo devastador, no centro de todos os interesses vitais e, por outro, é exatamente este o limite diante do qual quase toda relaçấo humana fracassa, entăo desaparece, cada vez mais, assim no plano natural como no ético, a confiança irrefletida, o repouso e a saúde. (BENJAMIN, 2012c, p. 20)

Toda essa discussăo de Benjamin torna-se ainda mais interessante quando ele analisa a moda. Para Benjamin, a moda traz consigo formas de exclusâo social daqueles que năo se adequam aos padróes por ela desenvolvidos. A moda é um dos exemplos, para Benjamin (2006, p. 45), do fetiche da mercadoria do qual Karl Marx tratava. Ela 
incentiva a ideia do novo, que na realidade é o velho reinventado para ser vendido. Ela estimula a obsessấo por padrōes uniformes, sem a possibilidade da diferença.

Para Benjamin, a moda é a morte da mulher:

Pois a moda nunca foi outra coisa senáo a paródia do cadáver colorido, provocaçăo da morte pela mulher, amargo diálogo sussurrado com a putrefaçăo entre gargalhadas estridentes e falsas. Isso é a moda. Por isso ela muda tâo rapidamente; faz cócegas na morte e já é outra, uma nova, quando a morte a procura com os olhos para bater nela. (BENJAMIN, 2006, p. 102)

A questăo do novo reinventado trata-se, para Benjamin (2006, p. 103), do que ele chama de espetáculo dialético da moda, esse ciclo de produçăo de novos padrôes a serem seguidos, a todo tempo. Benjamin (2012, p. 181) reconhece que a obra de arte sempre foi reproduzível, mas que "[...] mesmo na reproduçăo mais perfeita, um elemento está ausente: o aqui e agora da obra de arte, sua existência única, no lugar em que ela se encontra. É nessa existência única, e somente nela, que se desdobra a história à qual ela estava submetida no curso da sua existência".

Para Benjamin (2012, p. 182), a esfera da autenticidade é perdida com a reprodutibilidade técnica. Tal declínio da aura acontece por alguns motivos: primeiramente, porque na sociedade de massa se pretende deter os objetos de modo palpável e próximo, o que incentiva a cópia. Isso é fomentado pelos meios de comunicaçăo (BENJAMIN, 2012a, p. 184). O cinema, por exemplo, é uma forma de arte questionada por Benjamin, já que consegue modificar a atuaçâo dos atores, a significaçâo das cenas, até alcançar a perfeiçăo desejada. Benjamin questiona se a obra de arte năo seria justamente o oposto da perfeiçâo:

Com o cinema, a obra de arte adquiriu um atributo decisivo, que os gregos ou năo aceitariam ou considerariam o menos essencial de todos: a perfectibilidade. [...] Para os gregos, cuja arte visava a produçăo de valores eternos, a mais alta das artes era a menos perfectível, a escultura, cujas criaçóes se fazem literalmente a partir de um só bloco. Daí o declínio inevitável da escultura, na era da obra de arte montável. (BENJAMIN, 2012a, p. 190)

Ainda sobre o cinema, ele seria o criador de padrôes a serem seguidos pela sociedade, estimulando a participaçăo das massas em ideais ilusórios. Atinge, principalmente, as mulheres.

Benjamin afirma que a indústria cinematográfica tem todo interesse em estimular a participaçăo das massas por meio de concepçóes ilusórias e especulaçóes ambivalentes. Seu êxito maior é com as mulheres, que passam a confiar nos ideais de vida impostos pelo cinema: a família feliz, a mulher que serve ao marido e aos filhos. Com esse objetivo, a indústria cinematográfica mobiliza um poderoso aparelho publicitário, pôe a seu serviço a carreira e a vida amorosa das estrelas, organiza plebiscitos, realiza concursos de beleza. Tudo isso para corromper e falsificar o interesse original das massas pelo cinema, totalmente justificado, na medida em que é um interesse pelo seu próprio conhecimento e, desse modo também, pelo conhecimento da classe. Benjamin (2012, p. 200) compara o capital cinematográfico com o fascismo: ele explora secretamente, no interesse de uma minoria de proprietários, a inquebrantável aspiraçâo por novas condiçōes sociais. 
A seguir, será analisada a visăo de Herbert Marcuse, que nasceu seis anos após Benjamin.

\section{HERBERT MARCUSE E AS FALSAS NECESSIDADES CRIADAS PELO PRINCIIPIO DO DESEMPENHO}

Herbert Marcuse nasceu em Berlim em 1898 e faleceu em 1979. Formou-se e doutorou-se em filosofia. Foi orientado por Martin Heidegger, desenvolvendo uma tese sobre Hegel.

Ele participou, em 1918, do movimento revolucionário spartakista, tendo sido eleito, neste ano, membro de um soviete de soldados berlinenses (DELACAMPAGNE, 1997, p. 140). O fracasso da revoluçâo alemá de novembro de 1918, bem como a liquidaçâo do movimento espartaquista marcaram a obra do autor.

Em 1934, devido à ascensăo do nazismo, Marcuse mudou-se para os Estados Unidos, onde conviveu com Adorno e Horkheimer e desenvolveu estudos com a Escola de Frankfurt. Em 1942, para sobreviver, ele aceitou trabalhar para o governo estadunidense, tendo inclusive elaborado um relatório durante a Guerra Fria sobre os potenciais do comunismo mundial (DELACAMPAGNE, 1997, p. 213). Em 1951, ele pediu demissâo do cargo e retomou sua carreira acadêmica.

Em 1968, Marcuse voltou à Europa temporariamente, aproximando-se do líder estudantil Rudi Dutschke, o qual contribuiu para a disseminaçáo das suas ideias, especialmente no contexto de maio de 68. Marcuse foi referência para os movimentos revolucionários da Europa na década de 1960. Esteve presente no movimento Black and Power, participou das insurreiçôes estudantis contra a guerra no Vietná.

No presente ensaio a obra de Marcuse será analisada com destaque para os escritos que discutem as consequências do avanço da tecnologia e como isso afeta as liberdades individuais e a razâo humana, com o propósito de destacar a formaçáo dos indivíduos a partir da discussâo de sua autonomia e fenômenos de alienaçăo.

Para tanto, serăo utilizadas como base duas obras marcusianas da fase da teoria crítica da sociedade, quais sejam Eros e civilizaçâo: uma interpretaçâo filosófica do pensamento de Freud e A ideologia da sociedade industrial, bem como um texto publicado em 1972, denominado Novas fontes para a fundamentaçâo do materialismo histórico. Ademais, serăo também discutidas as visóes de alguns estudiosos de referido autor: Francisco Antônio Dória e André Nicolas.

Primeiramente, é marcante na obra de Marcuse a ideia de que a interferência que a alienaçăo provoca na sociedade, nâo ocorre somente do ponto de vista econômico, mas, ainda, na relaçâo do sujeito consigo mesmo, com aqueles com quem convive, em várias esferas de sua vida: "A exteriorizaçăo e a alienaçăo atingem, além da esfera das relaçôes econômicas, a essência e a realidade do homem 'como homem', e somente por este motivo é que a perda do objeto do trabalho tem uma significaçâo tăo importante." (MARCUSE, 1972b, p. 17).

É importante notar que razâo humana, para Marcuse, conforme Dória (1979, p. 14), deve ser compreendida no sentido hegeliano, como o desenvolvimento das potencialidades do indivíduo de modo inteiramente livre. Marcuse (1972a, p. 103) 
pretende resgatar a potencialidade do ser humano, já que ela se encontra alienada pelo capitalismo: "A eliminaçâo das potencialidades humanas do mundo de trabalho (alienado) cria as pré-condiçôes para a eliminaçăo do trabalho do mundo das potencialidades humanas.".

Ademais, a ideia heideggeriana de homem projeto também está presente na proposta de Marcuse, já que ele quer desenvolver entre os indivíduos uma atitude revolucionária. Marcuse (1972a, p. 23) acredita que a revoluçăo poderá modificar o contexto capitalista por ele criticado: "Hoje, a luta pela vida, a luta por Eros, é a luta política".

A ideia de razăo em Marcuse, como possibilidades do sujeito, liga-se ainda à ideia de necessidade. Ele denuncia a fragilidade das necessidades do ser humano e a importância de se analisar a amplitude das reais possibilidades humanas. Dória (1979, p. 18) afirma que:

Para Marcuse, como para Georg Lukács e mesmo para Marx, o Marx de um texto muito pouco divulgado ainda [...], os Fundamentos da Crítica à Economia Política, o racionalismo, a tendência das sociedades modernas à administraçăo total, à tecnocracia burra, à planificaçấo de todos os setores da vida tem sua origem no mercantilismo burguês.

Marcuse afirma que se desenvolvem na sociedade necessidades humanas que năo condizem com o real poder da Razăo, a partir de suas potencialidades intrínsecas. Em Ideologia da sociedade industrial é posto que as necessidades que os indivíduos seguem săo muitas vezes falsas necessidades:

Podemos distinguir tanto as necessidades verídicas como as falsas necessidades.
"Falsas" săo aquelas superimpostas ao indivíduo por interesses sociais particulares
ao reprimi-lo: as necessidades que perpetuam a labuta, a agressividade, a miséria
e a injustiça. Sua satisfaçáo pode ser assaz desagradável ao indivíduo, mas a
felicidade deste náo é uma condiçáo que tem de ser mantida e protegida caso
sirva para coibir o desenvolvimento da aptidáo (dele e de outros) para reconhecer
a moléstia do todo e aproveitar as oportunidades de cura. Entăo, o resultado
é euforia na infelicidade. A maioria das necessidades comuns de descansar,
distrair-se, comportar-se e consumir de acordo com os anúncios, amar e odiar o
que os outros amam e odeiam, pertence a essa categoria de falsas necessidades.
(MARCUSE, 1973, p. 26.)

Ora, isso também pode ser perceptível na atualidade. Os indivíduos passam a acreditar que săo felizes, já que cumpridas as necessidades impostas pela comunicaçâo de massa, de um modo autoritário e sem a participaçăo individual dos sujeitos. Tanto as necessidades, quanto a felicidade, năo săo construídas individualmente, de dentro para fora, mas sim pela comunicaçăo de massa, pelas instituiçóes de poder e pelos interesses comerciais das corporaçôes. Com isso, escreve Marcuse, o indivíduo perde a consciência de que suas noçôes e necessidades săo impostas de fora para dentro, sem a sua participaçăo, falta a noçâo consciente da repressâo.

Marcuse (1972a, p. 102) sugere que a noçăo consciente da repressấo, predominante é obnubilada no indivíduo pela restriçấo manipulada de sua consciência. Esse processo altera o conteúdo de felicidade. Com o declínio da consciência, com o controle da informaçâo, com a absorçấo do indivíduo na comunicaçâo em massa, o conhecimento é administrado e condicionado. O indivíduo năo sabe exatamente o que se passa, já que a 
máquina esmagadora de educaçáo e entretenimento o une a todos os outros indivíduos, num estado de anestesia.

Sobre as comunicaçôes de massa, Marcuse (1972a, p. 97) afirma que o rádio e a televisáo invadem a consciência humana, fazendo com que o sujeito náo mais busque os valores dentro da sua criaçăo familiar, mas, sim, nesses meios de formaçăo de padrōes.

Para Marcuse, a libertaçăo burguesa representa certo paradoxo, já que permitiu que aquela sociedade pudesse experimentar a construçấo da sua liberdade, sem as amarras do sistema feudal e regido pelos ditames da Igreja. Mas, por outro lado, o capitalismo passou a preencher o que sâo as necessidades do ser humano, o que ele deve buscar, qual a forma de ele viver e agir. Para Marcuse, a real felicidade só será atingida na medida em que se puder viver de acordo com a realizaçáo dos desejos, sem as amarras impostas pelas situaçóes sociais. A isto se relaciona a atitude revolucionária por ele fomentada, conforme já adiantado anteriormente.

Marcuse (1972a, p. 25) propóe que as categorias psicológicas na sua sociedade estariam deixando de ser individuais, tornando-se problemas políticos existentes na esfera pública: "A tarefa é, antes, a oposta: desenvolver a substância política e sociológica das noçôes psicológicas".

Além da relaçâo com Freud, Dória (1979, p. 36) afirma que a teoria de Marx exerce influência em Marcuse, a partir de dois planos, a crítica ao capitalismo e a sua influência para além da categoria econômica:

O primeiro é a crítica, hoje tăo generalizada e conhecida, que Marx faz do capitalismo, quanto à submissáo que este sistema impóe ao trabalhador. 0 segundo plano é muito mais amplo e muito mais sério: o capital fixo passando a ser controlador e organizador de nossa vida de todos os dias - e năo, genericamente uma categoria econômica como o capital, mas sim os "órgáos da mente humana criados pela măo humana", todas as máquinas e mediadores entre nós e a Natureza que as ciências desenvolveram -, alguma coisa que é produçâo original nossa, que de nós dependia, passou a ser o motivo organizador de nossas vidas. Portanto, se nós estamos submetidos a uma organizaçâo que, em seu surgimento dependia de nós, e se nós esquecemos essa dependência original, nós nos alienamos frente ao que era nosso. $O$ que equivale dizer, nós nos alienamos de nós mesmos. (DÓRIA, 1979, p. 36)

Além das influências de Freud e Marx, o professor de Marcuse, Heidegger, é responsável por vários caminhos traçados na sua obra. Há, porém, uma significaçăo que separa Marcuse de seu professor: aquela referente à essência do humano. Ambos concordam na ideia do indivíduo como projeto, a facticidade do mundo presente e o projeto constituído pelo futuro como constituintes da dialética do viver. Para Dória (1979, p. 160), isso é perceptível na obra marcusiana no instante em que a pessoa, lançada no mundo, detém um horizonte ideológico, o qual é influenciado pelo capitalismo. Mas, para Heidegger, a essência do ser humano é o Nada.

Concorda-se com Dória ao interpretar o homem projeto de Marcuse. Inclusive, quando referido autor trata da libertaçâo burguesa das amarras do feudalismo, fica evidente que surge para aquele ser humano um universo de possibilidades de escolha, universo este que, infelizmente, é tomado pelos padrōes capitalistas. Nesse cenário, 
para Marcuse, a essência do indivíduo estaria na desalienaçăo, ou seja, na conquista da felicidade (DÓRIA, 1979, p. 161).

Trata-se, neste ponto, do que Marcuse conceitua como a Grande Recusa, a negaçăo dos sujeitos de tudo aquilo que lhe é imposto e reproduzido:

\begin{abstract}
Essa Grande Recusa é o protesto contra a repressăo desnecessária, a luta pela forma suprema de liberdade - "viver sem angústia". Mas essa ideia só podia ser formulada sem puniçăo na linguagem da arte. No contexto mais realista da teoria política ou mesmo da Filosofia, foi quase universalmente difamada como utopia.

A relegaçăo de possibilidades reais para a "terra de ninguém" da utopia constitui, só por si, um elemento essencial da ideologia do princípio de desempenho. Se a construçăo de um desenvolvimento instintivo náo-repressivo se orientar, năo pelo passado sub-histórico, mas pelo presente histórico e a civilizaçăo madura, a própria noçăo de utopia perde o seu significado. A negaçáo do princípio de desempenho emerge náo contra, mas com o progresso da racionalidade consciente; pressupóe a mais alta maturidade da civilizaçăo. (MARCUSE, 1972a, p. 139)
\end{abstract}

Marcuse, portanto, expóe a necessidade da grande recusa e já responde algumas críticas a ele endereçadas, de que suas propostas soam como utopia. Referido pensador acredita na possibilidade de uma civilizaçăo madura, que saiba tratar seus instintos de modo consciente. A ideia de atitude revolucionária de Marcuse (1972a, p. 226) consiste justamente na libertaçăo do indivíduo daquilo que é determinado pelo meio em que está inserido.

André Nicolas (1971, p. 29), quando estuda a teoria de Marcuse nesse tocante, trabalha a importância que a filosofia assume na proposta marcusiana. A filosofia é um exemplo daquilo que năo se submete a sistemas formais, compreendendo como fundamental a ligaçấo entre teoria e prática. Daí, mais uma vez, a noçâo do homem projeto, do indivíduo capaz de transformar a sociedade, a partir das possibilidades humanas. Os indivíduos devem ser capazes de sair da reificaçăo.

Em Eros e civilizaçâo, Marcuse, partindo da teoria freudiana, pretende interpretá-la para a sociedade como um todo e, náo, de um ponto de vista psicologicamente individual. Ele começa a partir do conceito de pulsăo de Freud. Pulsăo, conforme Dória (1979, p. 179), é um desejo, uma tendência ao movimento. Mas, de uma perspectiva freudiana ampla, há também a pulsâo pela vida (Eros) e para a morte (Thânatos). A partir das pulsôes, já que o sujeito precisa contê-las de alguma forma, Marcuse analisa outro conceito de Freud: a repressâo: "Freud nos mostra como o bloqueio é tal que seu rompimento, embora satisfazendo a pulsăo, representaria uma fonte de desprazer." (DÓRIA, 1979, p. 181).

A repressâo das pulsóes está relacionada ao princípio de realidade, o qual significa o momento em que o ser humano percebe que o mundo à sua volta deve ser controlado. Marcuse, todavia, entende que há um princípio de realidade extremo, denominado da mais repressâo, "[...] que é o excesso de repressáo desenvolvido pelos sistemas sociais, e que será o real causador da infelicidade humana" (DÓRIA, 1979, p. 182).

Concorda-se com a interpretaçâo de Dória (1979, p. 188), quando este afirma que o princípio de realidade da mais repressăo na contemporaneidade é reformulado como o princípio do desempenho, no sentido de que os indivíduos competem desenfreadamente entre si, na busca de um máximo idealizado pelos sujeitos. Ou seja, ainda na 
sociedade atual os indivíduos vivem guiados pelas amarras impostas a eles, numa busca incessante de atingir os padrôes determinados pelo capitalismo e entrando numa competiçăo com os demais. Em Eros e civilizaçâo, isso fica evidente:

O argumento que condiciona a libertaçăo a um nível de vida superior serve com excessiva facilidade para justificar a perpetuaçáo da dominaçăo. A definiçăo do nível de vida em termos de automóveis, televisóes, avióes e tratores é a do próprio princípio de desempenho. Além do critério implícito nesse princípio, o nível de vida poderia ser medido por outros critérios: a gratificaçáo universal das necessidades humanas básicas e a liberdade contra a culpa e o medo. (MARCUSE, 1972a, p. 141)

O trabalho, para Marcuse, era um dos exemplos de atuaçâo do princípio do desempenho. Os indivíduos trabalham cada vez mais, com o mínimo de escolha de suas atividades e funçóes. Marcuse afirma que, para a esmagadora maioria da populaçăo, a extensâo e o modo de satisfaçâo sâo determinados pelo seu próprio trabalho. Nesse cenário, Marcuse (1972a, p. 58) dispóe que os humanos nâo vivem sua própria vida, mas desempenham tăo só funçôes preestabelecidas. Enquanto trabalham, năo satisfazem suas próprias necessidades e faculdades, mas trabalham em alienaçăo.

Ele afirma que o trabalho tornou-se geral, assim como as restriçōes impostas à libido: o tempo de trabalho, que ocupa a maior parte da vida de um indivíduo, é um tempo penoso, visto que o trabalho alienado significa ausência de gratificaçăo, negaçăo do princípio de prazer; a libido é desviada para desempenhos socialmente úteis, em que o indivíduo trabalha para si mesmo somente na medida em que trabalha para o sistema, empenhado em atividades que, na grande maioria dos casos, năo coincide com suas próprias faculdades e desejos (MARCUSE, 1972a, p. 58).

O local em que o princípio de realidade ainda náo se manifestou era denominado por Marcuse como fantasia, o que permite relacionar sua concepçâo de obra de arte com o conceito desenvolvido por Walter Benjamin. Pode-se dizer que Marcuse e Benjamin se aproximam na sua interpretaçăo da arte. Benjamin afirma que qualquer artista, na produçăo de sua arte, exerce de alguma forma uma crítica à sociedade. Marcuse vai além, dispondo ainda que a arte é a manifestaçâo da fantasia, sendo fantasia o espaço em que o princípio de realidade ainda năo se manifestou (DÓRIA, 1979, p. 197).

É interessante a análise que Dória (1979, p. 235) realiza da Ideologia da sociedade industrial, em que trabalha alguns pares contraditórios tratados por Marcuse, como sendo aqueles que os indivíduos experimentam: um Estado que pretende promover as necessidades dos indivíduos, mas que, ao mesmo tempo, torna-se cada vez mais beligerante; e uma indústria que se torna cada vez mais tecnológica e, por isso, ao mesmo tempo mais revolucionária.

Marcuse afirma que o desenvolvimento tecnológico e suas mazelas pode ser claramente enxergado no crescimento paralelo da tecnologia bélica e nos seus efeitos trágicos. Dispōe que:

A capacidade de matar e queimar em grandes proporçóes, e o comportamento mental que lhe é concomitante, sấo subprodutos do desenvolvimento das forças produtivas, dentro de um sistema de exploraçāo e repressáo; parecem essas forças tornar-se tanto mais produtivas quanto mais confortável o sistema vai ficando para seus privilegiados sujeitos. A sociedade afluente demonstrou agora que é uma sociedade 
em guerra; se os seus cidadăos năo o notaram, as suas vítimas já o perceberam, por certo. (MARCUSE, 1972a, p. 18)

Tais definiçôes bem exemplificam a sociedade vivida por Marcuse. Elas se relacionam ainda ao conceito de produtividade existente na obra marcusiana, a qual contribui para o processo de alienaçăo dos indivíduos. Marcuse (1973, p. 29) afirma que um dos aspectos mais perturbadores da civilizaçâo industrial desenvolvida é o caráter racional da sua irracionalidade. A produtividade e eficiência da sociedade, sua capacidade para aumentar e disseminar comodidades, para transformar o resíduo em necessidade e a destruiçấo em construçăo e o grau com que essa civilizaçăo transforma o mundo objetivo numa extensăo da mente e do corpo humanos tornam questionável a noçăo de alienaçăo. Ainda que as pessoas se reconhecem em suas mercadorias, encontram sua alma em seu automóvel, casa em patamares, utensílios de cozinha.

Marcuse destaca também o fato de que o desenvolvimento da tecnologia na sociedade industrial é fomentado, mas, ao mesmo tempo, constantemente contido, para nâo promover, ao final, a plena liberdade do sujeito. Liberdade, em Marcuse, conforme Dória:

[...] significa muito menos a possibilidade de decidirmos entre um certo número de opçóes que a possibilidade de construirmos, nós mesmos, as opçóes a serem escolhidas. Porque afinal alguma coisa se falseou quando admitimos acriticamente as opçôes que nos foram oferecidas, e quando me esqueço de perguntar a respeito da possibilidade de haverem outras opçôes que năo as que tenho no presente momento. Por que me devo submeter a um código moral que sinto ser, antes de tudo, inadequado? 0 código moral é o sistema pré-fixado de opçôes; a real liberdade começa quando contestamos o valor absoluto, o apriorismo do código moral. (DÓRIA, 1979, p. 237)

Ou seja, a real liberdade é aquela que năo escolhe entre várias opçōes externamente colocadas, mas, sim, a que constrói os próprios objetivos e rumos, sem uma ligaçâo necessária com aquilo que a sociedade capitalista estabelece. Em Ideologia da sociedade industrial, Marcuse argumenta que há uma perda da reflexăo sobre se ter uma real liberdade entre as pessoas, por meio da submissăo ao sistema de ideologias ali vigente. Ele afirma que sob o jugo de um todo repressivo, a liberdade pode ser transformada em poderoso instrumento de dominaçăo. O alcance da escolha aberta ao indivíduo náo é o fator decisivo para a determinaçăo do grau de liberdade humana, mas o que pode ser escolhido e o que é escolhido pelo indivíduo. O critério para a livre escolha jamais pode ser absoluto, mas tampouco é inteiramente relativo. A livre escolha entre ampla variedade de mercadorias e serviços nâo significa liberdade se esses serviços e mercadorias sustêm os controles sociais sobre uma vida de labuta e temor, sob a alienaçăo. Marcuse (1973, p. 28) determina que a reproduçáo espontânea, pelo indivíduo, de necessidades impostas nâo estabelece autonomia, mas sim estipula a eficácia dos controles.

A partir disso, sociedade industrial, para Marcuse (1973, p. 24), é uma sociedade totalitária, no sentido de "[...] uma coordenaçăo técnico-econômica năo-terrorista que opera através da manipulaçăo das necessidades por interesses adquiridos.".

A partir de todo esse cenário, concretiza-se a alienaçâo denunciada por Marcuse, o indivíduo identifica-se cegamente com a sua sociedade e busca os padrôes de necessidade por ela estabelecidos. Nâo há desenvolvimento da própria individualidade e construçấo das necessidades de cada um, por isso é fundamental a Grande Recusa: 
O fato de a grande maioria da populaçăo aceitar e ser levada a aceitar essa sociedade năo a torna menos irracional e menos repreensível. A distinçăo entre consciência verdadeira e falta, entre interesse real e imediato, ainda têm significado. Mas a própria distinçấo tem de ser validada. O homem tem de vê-la e passar da consciência falsa para a verdadeira, do interesse imediato para o interesse real. Só poderá fazêlo se viver com a necessidade de modificar o seu estilo de vida, de negar o positivo, de recusar. É precisamente essa necessidade que a sociedade estabelecida consegue reprimir com a intensidade com que é capaz de "entregar as mercadorias" em escala cada vez maior, usando a conquista científica da natureza para conquistar o homem cientificamente. (MARCUSE, 1973, p. 17)

Marcuse (1972a, p. 98) destaca o fato de operários e capitalistas terem se tornado uma massa única, deixando de existir a luta de classes. Tal massificação é ocasionada pelo consumo. $O$ consumo e a sua criaçáo de necessidades nos indivíduos, de modo generalizado, provoca a busca cega e alienada do proletário e do capitalista dos mesmos ideais e necessidades, sâo todos vítimas inocentes.

Conforme visto, em Eros e civilizaçâo, Marcuse (1972a, p. 16) é claro em afirmar que a soluçấo para o Estado de Bem-Estar por ele criticado é um Estado em que os indivíduos constroem seus objetivos, podendo ativar necessidade biológicas que se encontram reprimidas. Libertaçăo, nesse contexto, é justamente "[...] a emergência de novas necessidades e faculdades, qualitativamente diferentes".

Inclusive, dirá Marcuse (1972a, p. 18), os países por ele chamados atrasados teriam a vantagem de nâo ter a tecnologia e a industrializaçăo tăo avançada, o que aumenta sua possibilidade de libertaçăo. O tempo livre, também, seria maior em referidas sociedades. Já naquelas mais desenvolvidas, em que o capitalismo se encontra mais avançado, até o tempo livre é guiado pelo trabalho, pelas metas e valores impostos pela economia de mercado. A pessoa existe só uma parcela de tempo, durante os dias de trabalho, como um instrumento de desempenho alienado. Teoricamente, o resto do tempo está livre para si próprio. Mas, o tempo livre é ínfimo dentro da dinâmica do trabalho (MARCUSE, 1972a, p. 59).

O progresso, para além da horda primordial - isto é, a civilizaçâo -, pressupóe o sentimento de culpa, que introjeta nos indivíduos e, portanto, sustém as principais proibiçôes, restriçóes e dilaçôes na gratificaçăo, das quais a civilizaçăo depende (MARCUSE, 1972a, p. 72). Assim, o momento do ócio, em que o ser humano pode dedicar-se ao prazer, é entendido pelo indivíduo como culpa. Marcuse inclusive discorre sobre a Igreja, afirmando que ela é uma instituiçăo que incentiva a introjeçăo do sentimento de culpa nos indivíduos:

Como é possível conceber uma auto-responsabilidade do homem diante da determinaçăo completa da vontade humana? A responsabilidade humana deve ser salva: isso é exigido pela doutrina cristá do pecado e da culpa, do castigo e da salvaçăo, mas é exigido também pelo sistema vigente da autoridade terrena que, como vimos, tanto para Lutero como para Calvino, está essencialmente relacionado ao mecanismo de culpa e castigo. (MARCUSE, 1972b, p. 77.)

Conforme já visto, a instituiçâo da família também é afetada, já que a ideia de se casar ou ter filhos é guiada pelas necessidades impostas pelo sistema capitalista, deixando de ser espaço de desenvolvimento e construçăo de valores. A realidade da família burguesa, como todas as formas de vida no capitalismo, é condicionada pelo caráter da 
economia de mercado; ela entra na contabilidade geral como um bem, com seus custos e gastos, lucro e mais-valia específicos. Os interesses econômicos săo determinados na escolha do cônjuge e na geraçăo e criaçáo dos filhos. Da mesma forma que as funçôes fisiológicas, também os valores espirituais săo relacionados necessariamente aos interesses econômicos (MARCUSE, 1972b, p. 146).

Ante esse cenário, como seria possível libertar o indivíduo das amarras do capitalismo? Primeiramente, a ideia de negatividade em Hegel é de relevância nos estudos desenvolvidos por Marcuse, para libertar o ser humano dessa situaçâo de alienaçâo. É importante destacar que o próprio Marcuse (1972b, p. 53) esclarece que, para Hegel, alienaçáo é justamente a ideia de autoexternalizaçăo do ser, na busca de sua liberdade.

Apesar disso, Marcuse utiliza esse termo em outro sentido, qual seja, o de perda de construçáo da própria identidade humana. Superada esta questăo conceitual, partindo da interpretaçấo de Dória (1979, p. 169), a negatividade, num primeiro momento, relaciona-se com a perda, pelo mundo cotidiano, da sua solidez, a partir de reflexóes e questionamentos que o sujeito estabelece acerca desse mundo. A negatividade continua a atuar no momento em que o ser humano rompe com a visáo de dentro do mundo, abrindo-o a novas possibilidades, por meio da dialética sujeito e objeto. Escreveu Marcuse:

A força da negaçăo, como sabemos, náo está hoje concentrada em classe alguma. Ela hoje ainda é uma oposiçăo caótica e anárquica, política e moral, racional e instintiva: a recusa a participar e colaborar, o nojo diante da toda prosperidade, o impulso de protesto é uma oposiçăo débil e năo organizada. Mas, creio ela se baseia em impulsos e objetivos que se encontram em contradiçăo irreconciliável com o todo existente. (MARCUSE, 1972b, p. 165)

Em Eros e civilizaçâo, Marcuse também desenvolve soluçōes para que o indivíduo, enfim, alcance a felicidade: a substituiçáo do labor pela atividade lúdica, a conquista do tempo e a autossublimaçâo da razâo. Tais propostas, que poderiam ser sintetizadas no conceito de Grande Recusa, seriam capazes de resgatar os direitos e liberdades do sujeito, perdidos em meio ao capitalismo. Para Marcuse (1973, p. 23), os direitos e liberdades que foram fatores vitais nas origens e fases iniciais da sociedade industrial renderam-se a seu sentido lógico e conteúdo tradicional. Liberdade de pensamento, liberdade de palavra e liberdade de consciência foram ideias essencialmente críticas destinadas a substituir uma cultura material e intelectual obsoleta por outra mais produtiva e racional. Uma vez institucionalizados, esses direitos e liberdades compartilharam o destino da sociedade da qual se haviam tornado parte integral.

O jogar do sujeito, para Marcuse, é justamente deixar que suas potencialidades estejam presentes. Deve-se entender que a libertaçăo nâo é transcendente, íntima ou, meramente, uma liberdade intelectual, mas, uma liberdade na realidade. Marcuse (1972b, p. 167) entende que a realidade que perde a sua seriedade é a realidade inumana da carência e da necessidade, e perde a sua seriedade quando as carências e necessidades podem ser satisfeitas sem trabalho alienado. Entăo, o indivíduo está livre para jogar, tanto com suas próprias faculdades e potencialidades como as da natureza e, só a jogar com elas, torna-se livre.

Marcuse propōe uma reconciliaçăo revolucionária entre a racionalidade técnica e as aspiraçôes individuais à felicidade. Isso envolve uma reapropriaçăo do 
espaço privado, recusando-se as formas autoritárias de colonizaçăo da vida cotidiana (DELACAMPAGNE, 1997, p. 215).

A seguir, será visto como Theodor Adorno e Max Horkheimer desenvolveram algumas ideias trabalhadas por Marcuse e, ainda, tratou de outros institutos que marcavam a sua época.

\section{THEODOR ADORNO, MAX HORKHEIMER E A MASSIFICAÇÃO DA SOCIEDADE}

Theodor Adorno nasceu em 1903 na Alemanha e faleceu em 1969. Doutorou-se na Universidade de Frankfurt, sua cidade natal, e em seguida passou um período em Viena, estudando música. O referido pensador é central para o desenvolvimento do presente ensaio, já que ele é um dos principais expoentes da Escola de Frankfurt, ao lado de Max Horkheimer.

Para Adorno, ao se analisar as estruturas e práticas sociais é necessária a adoçâo de uma dialética negativa, no sentido de que a história universal deve construir-se e negar-se. O domínio da natureza tornou o ser humano alienado e reificado, de modo que o progresso e a emancipaçăo săo, na realidade, escravizaçăo (MORA, 1988, p. 62). A dialética negativa exclui toda conceitualizaçáo definitiva e tem em conta o movimento incessante do pensamento (MORA, 1988, p. 63).

Serăo analisados alguns conceitos adornianos, tais como a indústria cultural e a sociedade de massa. A expressāo indústria cultural (Kulturindustrie), para Adorno, diz respeito, num primeiro momento, à submissáo das obras de arte ao capitalismo, as quais se tornam também produtos supérfluos e com isso contribuem para a massificaçăo dos indivíduos. A ideia de indústria cultural aplicada às obras de arte é uma ocorrência em vários autores da Teoria Crítica, principalmente em Benjamin. Para além do estudo da submissâo das obras de arte aos padróes capitalistas, a Teoria Crítica amplia seu objeto e se debruça também sobre os efeitos do capital sobre os indivíduos.

O trabalho analisará o ensaio adorniano chamado Crítica cultural e sociedade, assim como as obras Minima moralia: reflexôes a partir da vida lesada e Dialética do esclarecimento: fragmentos filosóficos, esta última em coautoria com Max Horkheimer e que representa um grande legado deixado pela Teoria Crítica.

Adorno e outros pensadores da Teoria Crítica como, por exemplo, Benjamin, partem do pressuposto de que a arte é a maneira de expressăo livre do ser humano, e estaria apta a estabelecer processos críticos e em sentido contrário ao sistema em que está inserida. Mas, na dinâmica capitalista a arte perde seu caráter de denúncia e se converte num instrumento para o capitalismo.

Ao tratar da arte, Adorno afirma que esta deixou de representar a recusa à realidade, pretendendo aproximar-se dos indivíduos, numa dialética de ilusăo. Essa ideia de recusa liga-se diretamente à atitude revolucionária tratada por Marcuse, quando afirma que somente a partir da Grande Recusa, os indivíduos poderăo libertar-se dos padrôes capitalistas.

Partindo disso, Adorno propóe o postulado da falsidade total, determinando que “[...] a mentira é o estado permanente da sociedade atual, representando a alienaçáo 
radical traduzida pelas relaçóes com a totalidade. Tudo que emana daí só pode ser falso, jamais sendo o signo da verdade", conforme Marc Jimenez (1977, p. 88).

Essa ideia de uma sociedade calcada nas mentiras é recorrente em Adorno. Em sua obra Minima moralia, Adorno reúne aforismos acerca das instituiçôes que existiam à sua época. Para ele, a imoralidade da mentira năo consiste em ferir a verdade. Os indivíduos sentem-se incitados a viver numa farsa. Os sujeitos mentem a todo momento na sua convivência, pois a organizaçăo do mundo os obrigam a mentir se quiserem viver, os obrigam a permanecer adotando práticas de vida similares entre si, sem questionamentos (ADORNO, 2008, p. 26).

Ou seja, a indústria cultural cria mentiras e os indivíduos vivem guiados por tais concepçôes, reproduzindo aquilo que lhes é imposto, sem qualquer capacidade de crítica ou de questionamento. É a alienaçâo. Nesse ponto, surge ainda a concepçâo de mundo administrado (verwaltete Welt), no sentido de um conluio de poderes que criam uma ideologia a guiar a vida dos indivíduos. Inclusive, para Axel Honneth o conceito de mundo administrado nâo é tratado apenas por Adorno, mas permeia os estudos de Horkheimer e Marcuse (1999, p. 537).

A experiência de Adorno no Instituto de Pesquisas Sociais foi particularmente relevante na sua trajetória, já que ali se estabeleceu sua parceria com Max Horkheimer, com o qual escreveu uma das obras centrais da Teoria Crítica: Dialética do esclarecimento. Horkheimer aproximou-se de Adorno e disse-lhe, em dezembro de 1936, que apreciava particularmente o seu "[...] olhar aguçado pelo ódio àquilo que existe", ou seja, o seu espírito crítico, mas, nâo sistemático, a sua aptidāo para descobrir a face oculta das coisas (DELACAMPAGNE, 1997, p. 175). A partir disso, começou a parceria entre os dois estudiosos, que culminou na Dialética do esclarecimento.

É fundamental a análise dessa obra, já que representa um marco no questionamento da razăo instrumental, tăo em voga no século XX. Adorno e Horkheimer propuseram-se a questionar o suposto esclarecimento, tăo exaltado naquela época. Referidos autores descreveram o esclarecimento como uma tentativa de desencantamento do mundo, isto é, de colocar o indivíduo e a sua razăo como senhores absolutos.

Por isso mesmo, o esclarecimento de que falam năo é, como o Iluminismo, ou a Ilustraçăo, um movimento filosófico ou uma época histórica determinada, mas o processo pelo qual, ao longo da história, os sujeitos se libertam das potências míticas da natureza, ou seja, o processo de racionalizaçăo que prossegue na filosofia e na ciência.

Adorno e Horkheimer afirmam que, na realidade, o esclarecimento provocou a perda da autoconsciência do ser humano. Na medida em que pretende dominar demasiadamente a natureza, ele se perde e corre o risco de cair na barbárie. O poder de conhecimento humano provoca a perda de rumo dos indivíduos e o esclarecimento torna-se autodestrutivo.

Adorno, em Minima moralia, afirma que a consciência individual se perde pela crença do indivíduo numa aparente liberdade que, na realidade, pretende eliminar a possibilidade da diferença. Para Adorno, o modelo do ato de troca passa a dominar todas as relaçóes que circundam o ser humano. A consciência individual fica cada vez com menos espaço, passa a ser formada de antemăo, de um modo cada vez mais radical, 
cortando-lhe a priori a possibilidade da diferença, que se degrada em mera nuance no interior da homogeneidade da oferta. Simultaneamente, a aparência de liberdade é, na realidade, a própria năo liberdade, incomparavelmente mais difícil do que antes. Esses momentos, em conjunto com a seleçâo social dos portadores do espírito, têm como resultado a regressâo do espírito (ADORNO, 2008, p. 78).

As pessoas tornam-se massificadas, ou seja, quanto mais agir e desejar os mesmos ideais, a Humanidade será uniforme e o capitalismo permanecerá cada vez mais forte. Em Dialética do esclarecimento afirma-se que a ideia que o esclarecimento dissemina, de que o ser humano se tornou um eu todo-poderoso, capaz de dominar a natureza e sempre guiar-se pela razăo, transformou-se numa concepçăo de vida que se justifica a partir da detençăo de bens, de produtos, de consumo daquilo que a indústria cultural determina. $O$ esclarecimento pretendeu fazer com que os pensamentos humanos se tornassem autônomos em face dos objetos. Mas, ao invés disso, o próprio conhecimento tornou-se uma mercadoria, a ser reproduzido como um produto.

Esse processo é desenvolvido, segundo Adorno e Horkheimer, a partir da sociedade industrial, já que as máquinas tornaram os humanos seus escravos, mesmo que a princípio parecesse que elas serviriam ao desenvolvimento da Humanidade. A ascensâo da produtividade econômica torna os indivíduos impotentes e idiotizados pelo consumo.

Tais autores estabelecem que o esclarecimento só se superará quando o princípio da dominaçáo cega deixar de reinar. Para eles, o esclarecimento converte-se na total mistificaçấo das massas. Criam-se mitos para que a sociedade acredite neles e os reproduza. Um destes mitos, por exemplo, é o casamento. A mulher tornou-se uma representaçăo da impotência e ao mesmo tempo da seduçấo, sendo o casamento uma maneira de colocá-la sempre como ser submisso:

A prostituta e a esposa săo elementos complementares da auto-alienaçăo da mulher no mundo patriarcal: a esposa deixa transparecer prazer com a ordem fixa da vida e da propriedade, enquanto a prostituta toma o que os direitos de posse da esposa deixam livre e, como sua secreta aliada, de novo o submete às relaçóes de posse, vendendo o prazer. 0 casamento é um exemplo de primeiros mitos da civilizaçáo. (ADORNO; HORKHEIMER, 1985, p. 75.)

Ainda sobre a mulher, Adorno e Horkheimer ressaltam mais uma vez a tentativa de uniformizaçăo de padróes à sua época impostas às mulheres, isto é, a construçâo individual de vida de cada uma destas era negada pela sociedade burguesa, sendo todas elas colocadas numa massa padronizada: "O homem dominador recusa à mulher a honra de individualizá-la" (ADORNO; HORKHEIMER, 1985, p. 106).

Adorno, em Minima moralia, trabalha a ideia de feminilidade, como um produto construído pelo sistema capitalista, que estipula as maneiras e trejeitos que a mulher feminina e dócil deve reproduzir. Ele afirma que a feminilidade reproduzida pelas mulheres é sempre exatamente aquilo que toda mulher é levada a impor a si com toda força - com força masculina. Ele usa a expressâo "[...] as mulherzinhas săo homenzinhos". Adorno afirma que as mulheres femininas usam e manipulam a sua feminilidade, a colocam em cena conforme a necessidade, fazem luzir os olhos, se servem do seu temperamento para saber o que vem a ser esse inconsciente protegido e náo atingido pelo intelecto. Sendo assim, a glorificaçăo do caráter feminino envolve a humilhaçâo de todas as que o trazem (ADORNO, 2008, p. 91). Percebe-se, portanto, que Adorno, em 
meados do século XX, já questionava as definiçóes de gênero impostas pela sua sociedade, argumentando, conforme visto, que a própria divisâo homem/mulher já era uma forma de padronizar e massificar os indivíduos.

Em Dialética do esclarecimento há também o questionamento dos meios de comunicaçăo, como o rádio e o jornal, como portadores de um caráter manipulador da consciência dos indivíduos: "Os talentos já pertencem à indústria muito antes de serem apresentados por ela." (ADORNO; HORKHEIMER, 1985, p. 115). Ou seja, aquilo que é reproduzido pela indústria cultural teria sido cuidadosamente preparado para convencer e manipular o público. Desenvolvem-se a priori os gostos e preferências, para que em seguida os lançamentos correspondam àquilo que os indivíduos falsamente pensam que desejam receber como entretenimento. Os indivíduos, na realidade, sâo apenas consumidores reduzidos a números.

Săo fenômenos de uniformizaçăo dos meios técnicos, daquilo que é informado e reproduzido à populaçăo e, consequentemente, a própria populaçăo tende a uniformizar-se, a reconhecer-se sempre nos mesmos estilos. Trata-se de submissáo cega e conformada, isto é, um processo de alienaçăo, criando conceitos e sugerindo valores e comportamentos.

Neste cenário, a propaganda surge como aliada ao processo de massificaçăo cultural. Adorno e Horkheimer usam como exemplo o fascismo, que muito se utilizou de tal ferramenta. O discurso utilizado pela propaganda fascista servia para dominar os sujeitos, cada vez mais cegos, determinando o seu modo de viver.

Além da propaganda, há também as associaçôes e personalidades, como produtores de padrōes a serem seguidos pelos indivíduos alienados. Neste sentido:

As associaçôes e as celebridades assumem as funçôes do ego e do superego, e as massas, despojadas até mesmo da aparência da personalidade, deixam-se modelar muito mais docilmente segundo os modelos e palavras de ordem dadas, do que os instintos pela censura interna. (ADORNO; HORKHEIMER, 1985, p. 190.)

Adorno e Horkheimer afirmam que as capacidades cognitivas do ser humano sâo prejudicadas em meio ao consumo estético massificado pela indústria cultural. $\mathrm{O}$ indivíduo torna-se um ser genérico, guiado principalmente por objetivos ligados ao consumo e à sua vida econômica: "O distúrbio está na incapacidade de o sujeito discernir no material projetado entre o que provém dele e o que é alheio" (ADORNO; HORKHEIMER, 1985, p. 175).

Os autores denominam de excessiva coerência paranóica a busca dos indivíduos por adaptar-se a padróes estipulados por estruturas capitalistas. As pessoas começam a construir a sua realidade pela engrenagem da indústria cultural, nâo mais exercendo a dialética sujeito e realidade que os cercam (ADORNO; HORKHEIMER, 1985, p. 181).

É ainda de se analisar o estudo que Adorno realiza sobre o trabalho, como uma ferramenta de submissăo coordenada pelo capitalismo, sendo inclusive o tempo de lazer guiado de acordo com o tempo de labor. Uma das formas de submissăo do sujeito ao capitalismo de modo alienado acontece também quando este năo questiona a exploraçăo que ocorre diariamente no ambiente de trabalho, bem como nos excessos e nas formas de diversáo, preestabelecidas, "[...] o tempo livre é acorrentado ao seu oposto" (ADORNO, 1985, p. 103). 
É bastante interessante o questionamento que Adorno realiza sobre o tempo livre. Para ele, a sensaçấo de liberdade no período em que os sujeitos năo estăo trabalhando é, na realidade, o exercício de uma náo liberdade, pois as formas trazidas pela diversáo e pelo entretenimento têm ligaçăo com a produçăo, pretendendo continuar a desenvolver na consciência humana a necessidade de trabalhar incessantemente. É o que Adorno denomina como pseudoatividades:

Preferem deixar-se desviar para atividades aparentes, ilusórias, para satisfaçóes compensatórias institucionalizadas, a tomar consciência de quăo obstruída está hoje tal possibilidade. Pseudoatividades săo ficçóes e paródias daquela produtividade que a sociedade, por um lado, reclama incessantemente e, por outro lado, refreia e năo quer muito nos indivíduos. Tempo livre produtivo só seria possível para pessoas emancipadas, náo para aquelas que, sob a heteronomia, tornaram-se heterônomas também para si próprias. (ADORNO, 1985, p. 113.)

Isto é, a ideia do ócio, do tempo livre efetivamente nos moldes que o próprio indivíduo quiser, só seria possível para aqueles indivíduos libertos dos padrôes e, portanto, que náo exercem a heteronomia também para si próprios. Náo seria isso o que ocorre na sociedade atual? As formas de diversâo que existem atualmente se ancoram na lógica do consumo e da vida acelerada pelo trabalho. Práticas cotidianas de alguns jovens como fazer compras no shopping, enfrentar longas filas nos restaurantes, conviver com o trânsito, frequentar ambientes que usualmente tocam músicas altas, potentes e que se relacionam diretamente ao consumo excessivo de bebidas e, em alguns casos, de drogas, caracterizam um perfil "moderno", "ligado":

O ritmo frenético da música tecno só năo é mais intenso do que as passadas largas e demarcadas nas esteiras elétricas. Eles sáo jovens e năo se contentam mais em praticar aquele tipo de exercício físico compassado, cujo aprendizado da melhor forma de se sentir a respiraçăo era tăo importante quanto o gradativo processo de tonificaçăo dos músculos. Nas atuais bicicletas ergométricas das academias de musculaçáo impressionam os gritos da instrutora da aula de spinning que, para ser ouvida pelos alunos, compete com a altura do ruído musical, cuja repetiçăo incessante da mesma batida passa a impressáo de que a vida só pode ser devidamente usufruída por meio de um outro ritmo: o da exaustâo. [...] Sáo estes mesmos jovens que, após a aula, vestem as camisas com as propagandas do curso de inglês realizado em Cambridge, da visita à Disney feita no verăo passado, do rosto de Che Guevara ou da defesa do meio ambiente. É a posse de logotipos que está em jogo, ou seja, numa sociedade na qual tanto as coisas quanto as pessoas se tornam cada vez mais substituíveis, faz-se necessário a demarcaçăo de algum tipo de ícone que possibilite o reconhecimento imediato daquele que o porta, que deixe algum vestígio. [...] 0 que verdadeiramente importa é possibilidade do portador da imagem de determinado ícone ser diferenciado dos demais que năo o possuem. É como se ele dissesse para si e para os outros: esse aqui sou eu, esta é a minha identidade! (ZUIN, 2003, p. 40.)

Adorno denomina peste do século XX: a pressa, o nervosismo e a instabilidade. Para ele, as grandes cidades desenvolvem a pressa, nervosismo e instabilidade e isso passa a expandir-se de modo epidêmico, como outrora a peste e a cólera. Todos têm que se dedicar a algo o tempo todo. 0 tempo livre exige ser gasto até o fim. Ele é planejado como empreendimento, preenchido com visitas a todos os eventos possíveis ou pelo menos com mudanças em velocidade máxima. A vida como um todo deve assemelharse à profissáo e esconder sob tal semelhança aquilo que ainda năo está dedicado de 
imediato ao ganho. Fazer coisas e ir a lugares é uma tentativa do aparato sensitivo de criar uma espécie de limiar de proteçâo contra a ameaçadora coletivizaçăo. Os indivíduos se adestram como membros da massa, precisamente nas horas aparentemente deixadas à liberdade. $O$ tédio do qual as pessoas fogem somente reflete o processo de fuga no qual há muito estâo envolvidas. É só por isso que se mantêm em vida e inflam cada vez mais o monstruoso aparato de entretenimento, sem que uma só pessoa tire divertimento disso (ADORNO, 2008, p. 136).

Para Adorno (2008, p. 133), a indústria cultural e os valores capitalistas refletemse nas mais variadas esferas de comportamento dos indivíduos. Até a linguagem se torna alienada, já que ela perdeu, na massificaçăo da sociedade, sua espontaneidade.

As escolas, afirma Adorno, adestram as pessoas na fala, mas os escolarizados tornam-se cada dia mais mudos. As pessoas sáo capazes de fazer conferências, cada sentença pode ser dita no microfone perante o qual eles săo colocados como representantes da média, mas a capacidade de falarem uns aos outros se sufoca, os indivíduos isolam-se. A descontraçăo e a objetividade na exposiçăo de fenômenos desaparecem mesmo no círculo mais íntimo, da mesma forma como na política há muito o debate foi substituído pela palavra de ordem. Os afetos, que na conversa humanamente digna diziam respeito ao conteúdo, aferram-se ao puro ter-se razăo, alheios a toda relevância do que se diz.

Adorno inclusive defende que a palavra relaçâo está intimamente ligada ao mercado, no sentido de que as relaçóes privadas săo tomadas por ele, năo fazendo mais sentido a construçấo de uma individualidade que nâo tenha como objetivo algo relacionado à acumulaçấo de riqueza. A construçâo de objetivos pessoais, nâo relacionados ao consumo coletivo, năo merece prosperar:

O conceito de relaçăo, uma categoria de intermediaçăo e circulaçăo, jamais se deu tâo bem na própria esfera da circulaçáo, no mercado, como em hierarquias fechadas, de tipo monopolar. [...] Antes, quando ainda havia algo como a difamada e já quase saudosa separaçăo burguesa entre profissăo e vida privada, seria visto com desconfiança, como um intruso sem maneiras, quem perseguisse metas na vida privada. Hoje é visto como arrogante, estranho e impertinente aquele que se envolve em coisas privadas sem exibir orientaçăo para uma meta. (ADORNO, 2008, p. 19.)

Percebe-se, portanto, que até a definiçăo de metas e sonhos individuais passam a orientar-se pela indústria cultural, a partir dos mitos por ela criados -por exemplo, o casamento. Adorno estabelece que é denominado de quase suspeito aquele sujeito que năo preestabelece objetivos corriqueiramente usados pelos membros da sociedade, ou seja, aquele indivíduo que ainda năo se submeteu ao sistema de metas imposto pelo capitalismo.

A partir dos aforismos de Minima moralia, Adorno desacredita da maioria das instituiçôes que circundavam o espaço humano: o casamento, a propriedade privada. Tudo estava corrompido pelo capitalismo, tudo estava eivado de mentira, todos aqueles que pensavam viver plenamente, de acordo com seus objetivos, só estavam tornando-se cada vez mais alienados. Mas, assim como a linguagem, o pensamento também perdeu sua espontaneidade.

A partir de todas as influências do capitalismo trazidas na obra de Adorno, o que mais interessa é o reflexo que elas ocasionam ao pensamento humano. Adorno (2008, 
p. 121) entende que fora roubado do pensamento seu componente espontâneo. Ele se reduz a disposiçôes substituíveis, permutáveis. Da mesma forma como se decide na economia bélica sobre prioridades na distribuiçâo de matérias-primas ou na fabricaçâo deste ou daquele tipo de arma, assim se infiltra na construçâo de teorias uma hierarquia de importâncias, com primazia para os temas especialmente atuais ou especialmente relevantes e com a postergaçăo ou a indulgente tolerância do năo fundamental, que apenas é admitido como ornamento dos fatos básicos.

Em Minima moralia, Adorno chega a afirmar que os indivíduos aptos a promoverem o desprendimento dos valores capitalistas já estariam alienados:

\begin{abstract}
Devemos nossa vida à diferença entre armaçáo econômica do industrialismo tardio e a fachada política. Para a crítica teórica a diferença é insignificante: em todo lugar pode-se expor o caráter fictício da suposta opiniâo pública e o primado da economia nas decisōes efetivas. Para inumeráveis indivíduos, no entanto, a casca fina e efêmera constitui o fundamento da própria existência. Precisamente aqueles dos quais depende a mudança, o unicamente essencial, devem sua existência ao náo essencial, à aparência, àquilo mesmo que na medida das grandes leis históricas de desenvolvimento pode ocorrer como mero acaso. Nâo será por isso afetada toda a construçăo de essência e aparência? Com efeito, se confrontado com o conceito, o individual tornou-se tăo irrelevante quanto o antecipava a filosofia de Hegel; da perspectiva da individualidade, entretanto, a contingência absoluta, o mero manter-se em vida como que anormal é ele próprio o essencial. (ADORNO, 2008, p. 109)
\end{abstract}

Ou seja, inclusive os sujeitos que poderiam modificar o cenário de alienaçăo, também estariam valorizando a aparência em detrimento da essência.

\title{
5. CONCLUSÃO
}

Há estudiosos que interpretam as obras dos autores da Teoria Crítica neste ensaio analisados como eivadas de certo pessimismo. Nâo há dúvidas de que referidos membros da Escola de Frankfurt trazem em seu discurso críticas a todas as esferas que circundavam a vida humana da sua época. Mas, em que pesem trechos como esse e interpretaçōes nesse sentido, entende-se que a Dialética do esclarecimento traz, em seu adendo, uma mençâo expressa a um possível resgate dos indivíduos a partir da sua construçấo individual de autonomia.

Adorno e Horkerheimer afirmam que é na autonomia e na incomparabilidade do indivíduo que se cristaliza a resistência contra o poder opressor do todo irracional. Por isso, os traços radicalmente individuais e irredutíveis de uma pessoa săo sempre duas coisas numa só: o que năo foi totalmente capturado pelo sistema dominante e sobrevive para sorte das pessoas e as marcas da mutilaçăo que o sistema inflige a seus membros (ADORNO; HORKHEIMER, 1985, p. 225).

Assim, haveria a possibilidade de o indivíduo preservar sua autonomia de pensamento, resistindo aos padrôes colocados. Também se deve destacar que, de modo geral para os pensadores da Teoria Crítica, a ideia de rompimento é latente, já que se pretende denunciar a sociedade industrial, com suas estruturas de alienaçâo dominantes, propondo-se uma nova maneira de se enxergar o mundo a partir do rompimento, da mudança, da quebra dos paradigmas. 
Adorno propóe que o indivíduo, vigilante, faça valer as suas exigências, somado a uma concepção estética da vida. Para Adorno, o filósofo deve fazer-se artista, enxergar a proximidade entre conceito e intuiçăo, verdade e loucura (DELACAMPAGNE, 1997, p. 182).

Conforme já dito, a intençáo do presente ensaio é estudar a Teoria Crítica para reinterpretar suas críticas à sociedade do século XX, com base na sociedade atual. É latente a ligaçáo dos estudos de Adorno e também dos outros autores aqui analisados com a reflexăo sobre autonomia dos indivíduos, inclusive no que se refere à sua relaçấo com o próprio corpo, inclusive envolvendo a patrimonializaçấo do corpo da mulher.

A partir dessa constataçăo, verifica-se a necessidade, nos nossos tempos, de se prezar pelo resgate da autonomia individual, já que muitas das características negativas descritas pela Teoria Crítica também sáo vislumbradas atualmente. Para tanto, as discussôes filosófico-sociológicas devem chegar às pessoas, devem integrar campanhas de conscientizaçấo e círculos de debate, para que o capitalismo náo seja simplesmente consumido e vivenciado sem questionamentos, mas sim sempre refletido e filtrado pela populaçấo. A liberdade está diretamente ligada com a independência do Homem na construçăo da sua identidade, o que só é possível se este estiver plenamente dotado de sua autonomia para viver e ser de sua forma única e insubstituível. 


\section{REFERÊNCIAS BIBLIOGRÁFICAS}

ADORNO, Theodor W. Minima moralia: reflexóes a partir da vida lesada. Traduçâo: Gabriel Cohn. Rio de Janeiro: Beco do Azougue, 2008.

; HORKHEIMER, Max. Dialética do esclarecimento: fragmentos filosóficos. Traduçăo Guido Antonio de Almeida. Rio de Janeiro: Zahar, 1985.

BENJAMIN, Walter. A obra de arte na era de sua reprodutibilidade técnica. In:

Magia e técnica, arte e política: ensaios sobre literatura e história da cultura. $1 .^{a}$ versâo.. Traduçăo: Sérgio Paulo Rouanet. Prefácio: Jeanne Marie Gagnebin. 8. ed. rev. Săo Paulo: Brasiliense, 2012a. (Obras Escolhidas v. 1)

Experiência e Pobreza. In: Magia e técnica, arte e política: ensaios sobre literatura e história da cultura. Traduçâo: Sérgio Paulo Rouanet. Prefácio: Jeanne Marie Gagnebin. 8. ed. rev. Săo Paulo: Brasiliense, 2012b. (Obras Escolhidas. v. 1)

. Passagens. BOLLE, Willi. (Org.). Belo Horizonte: UFMG; Sáo Paulo: Imprensa Oficial do Estado de Sáo Paulo, 2006.

Rua de mâo única. In:

Rua de măo única. Traduçăo: Rubens Rodrigues Torres Filho e José Carlos Martins Barbosa. Revisâo técnica Márcio Seligmann Silva. 6. ed. rev. Săo Paulo: Brasiliense, 2012c. (Obras Escolhidas, v. 2).

DELACAMPAGNE, Christian, História da filosofia no século XX. Traduçâo: Lucy Magalhăes. Rio de Janeiro: Jorge Zahar, 1997.

DÓRIA, Francisco Antônio. Marcuse: vida e obra. 2. ed. Rio de Janeiro: José Álvaro; Paz e Terra, 1974.

HONNETH, Axel. Teoria Crítica. In: GIDDENS, Anthony; TURNER, Jonathan (Orgs). Teoria Social Hoje. Traduçâo: Gilson César Cardoso de Sousa. Săo Paulo: UNESP, 1999.

HORKHEIMER, Max. Teoria crítica: uma documentaçăo. Traduçăo Hilde Cohn. Săo Paulo: Perspectiva, 2012. Tomo I.

. Teoria Crítica e Teoria Tradicional. In: Textos Escolhidos: Walter Benjamin, Max Horkheimer, Theodor W. Adorno, Jürgen Habermas. Traduçâo: José Lino Grünnewald et al. Săo Paulo: Abril Cultural, 1980. (Coleçăo Os Pensadores).

JIMENEZ, Marc. Para ler Adorno. Traduçáo: Roberto Ventura. Rio de Janeiro: Francisco Alves, 1977.

KOTHE, Flávio. Para ler Benjamin. Rio de Janeiro: Francisco Alves, 1976.

MARCUSE, Herbert. A ideologia da sociedade industrial. Rio de Janeiro: Zahar, 1973.

Eros e civilizaçâo: uma interpretaçâo filosófica do pensamento de Freud. 5. ed. Traduçâo Álvaro Cabral. Rio de Janeiro: Zahar, 1972a.

Novas fontes para a fundamentaçâo do materialismo histórico. In: Ideias sobre uma teoria crítica da sociedade. Rio de Janeiro: Zahar, 1972b.

MERQUIOR, Guilherme. Arte e sociedade em Marcuse, Adorno e Benjamin. Rio de Janeiro: Tempo Brasileiro, 1969. 
MORA, José Ferrater. Diccionario de filosofía. 6. reimp. Barcelona: Alianza, 1988. v. 1.

NICOLAS, André. Marcuse ou a busca de um universo transprometeico. Traduçăo: Franco de Sousa. Lisboa: Estúdios Cor, 1971. Traduçăo de: Herbert Marcuse ou la quête d'un univers trans-prométhéen.

ZUIN, Antônio Álvaro Soares. O corpo como publicidade ambulante. Revista

Perspectiva, Florianópolis, v. 21, n. 1, pp. 39-53, jan.-jun. 2003. 